\title{
On the Relation between Beach-Dune Dynamics and Shoal Attachment Processes: A Case Study in Terschelling (NL)
}

\author{
Filipe Galiforni-Silva ${ }^{*}+\mathbb{(}$, Kathelijne M. Wijnberg ${ }^{+}(\mathbb{C})$ and Suzanne J. M. H. Hulscher ${ }^{+}$ \\ Water Engineering \& Management, Faculty of Engineering Technology, University of Twente, P.O. Box 217, \\ 7500 AE Enschede, The Netherlands; k.m.wijnberg@utwente.nl (K.M.W.); s.j.m.h.hulscher@utwente.nl (S.J.M.H.H.) \\ * Correspondence: f.galifornisilva@utwente.nl \\ + These authors contributed equally to this work.
}

Received: 3 June 2020; Accepted: 14 July 2020; Published: 20 July 2020

\begin{abstract}
Inlet-driven processes are capable of modifying the adjacent shoreline. However, few studies have attempted to understand how these changes affect coastal dunes. The present study aims to understand how shoreline changes induced by shoal attachment affect coastal dunes. A barrier island in the Netherlands is used as a case study. Both bathymetric and topographic annual data were analysed, together with the application of a cellular automata model for dune development. The objective of the model is to explore idealised scenarios of inlet-driven shoreline movements. With the model, ten different scenarios were examined regarding beach width increase and rate of alongshore spreading of the shoal. Field data showed that, for the case study, dune volume and shoal attachments could not be directly linked. Instead, rates of dune volume change differed significantly only due to long-term ebb-tidal delta evolution. Such morphological evolution oriented the beach towards the main wind direction, increasing overall aeolian transport potential. Modelling results showed that shoals significantly increased dune volumes only on three out of ten scenarios. This suggests that beach width increase, and rate of alongshore sediment spreading, determine whether the shoal will influence dune growth. Therefore, within the studied time-scale, local rates of dune growth are only increased if shoals are capable of increasing the beach width significantly and persistently.
\end{abstract}

Keywords: shoal attachment; tidal inlets; dune growth; shoreline dynamics

\section{Introduction}

Coastal dunes are wind-driven accumulations of sand that naturally emerge in a coastal setting and are affected directly or indirectly by marine processes. When the wind blows across the beach surface, above a velocity threshold, it initiates aeolian sediment transport. Over time, this sediment deposits at the vegetated upper beach, leading to a bio-geophysical balance that controls dune initiation, growth and stabilisation [1-7]. For several countries, coastal dunes form an integral part of the coastal defence system. It prevents extreme storm surge events from reaching inland areas. Also, dunes may act as natural reservoirs of sand during both short and long-term erosive processes. Thus, coastal dunes are crucial in a risk and management perspective. Their maintenance and behaviour constitute a primary concern for researchers, managers and stakeholders.

Several mechanisms control coastal dune behaviour and development, such as sediment supply, vegetation, precipitation, wind climate, wave climate and geological characteristics of the surrounding area [8-11]. From those, beach morphology and beach width are very important aspects that control coastal dune development $[7,9,12,13]$. The morphological state of the beach (e.g., dissipative or 
reflective) influences the maximum capacity of onshore aeolian sediment transport, with dissipative beaches presenting the maximum potential for sediment delivery to the dunes [14]. Beach width appears to be the dominant factor in controlling both sediment transport from the beach and the total volume of sediment deposited on the dunes [12]. The authors of [7] show that beach width and available sediment supply control the position of dune development at a decadal scale. Changes in beach width due to shoreline sand waves and intertidal bar welding have also been linked to increased potential sediment supply and long-term accretion rates in foredunes [15-17].

In that sense, coastal dunes neighbouring inlets may have a particular behaviour due to the constant and cyclic changes in the adjacent shoreline driven by inlet-driven processes, such as shoal attachment and channel migration [18,18-22]. Particularly, shoals have a strong capacity to change adjacent coastlines in several temporal and spatial scales [23-26]. The authors of [27] attribute the shape of the East Frisian Islands to inlet sediment bypassing. The authors of [20] investigated shoreline migration trends in two inlet-driven regions in the West Coast of the United States associated with shoal attachment processes. The authors did not find any significant statistical relationship between the tidal prism and the longshore extent of the influence of the inlet on the adjacent shoreline. However, they found that downdrift inlet shoreline accretion dominates when stable bypassing processes occur. The authors of [28] state that, at Kiawah Island (US), the effect of shoal attachment was able to induce a beach progradation of over $1300 \mathrm{~m}$.

Considering the relation between beach width and dune development, current knowledge would suggest that dunes neighbouring tidal inlets would behave differently than those not affected by inlet-driven processes. Coastlines with frequent shoal attachment processes would have an increased potential for sediment transfer from the subtidal to the subaerial portion due to the increased beach width for certain periods of time. However, such behaviour has not been reported in the past, with only a few studies trying to understand how inlet-driven processes affect coastal dune development. In a study on inlet-associated beach systems in the Ireland coast, the authors [29] suggest that the dune may act as a sink zone for subaqueous inlet-driven shoals. In a study in a sand flat adjacent to the Marsdiep inlet (NL), the authors [11] show that dune volume is not spatially homogeneous over the sand flat. Over the sand flat, dunes tended to be larger in the more wave-exposed zone than in the more sheltered region due to spatial variations in supply conditions. Although the authors argue that groundwater level can induce such spatial variability on sand supply, other conditions such as inundation frequency [30] and storm-induced sand deposition [31,32] may also contribute to supply variability.

Therefore, the objective of the present study is to see whether or not there is consistent evidence to support the theory that consequent shoal attachment processes may change local coastal dune development in portions neighbouring tidal inlets. To investigate the objective, a case study in The Netherlands was chosen. The case was chosen because of the available long-term monitoring data, which is large enough to capture more than one attachment. Furthermore, an idealised numerical modelling approach was used to qualitatively test potential scenarios where shoreline change can or cannot induce changes in dune growth.

\section{The Island of Terschelling}

Terschelling is a barrier island located at the northern coast of the Netherlands (Figure 1). It has an orientation of about 73 degrees $\mathrm{N}$ [33], is approximately $30 \mathrm{~km}$ long, and 2-4.5 km wide. Median grain size ranges from $220-260 \mu \mathrm{m}$ at the foreshore zone to $150-160 \mu \mathrm{m}$ in the outer nearshore bar zone [34]. Waves approach the coast mainly from the NNW and SW directions, though the former is more prominent due to the orientation of the coast, which blocks the influence of SW waves. Tides are semi-diurnal and meso-tidal, with spring tidal range of $2.8 \mathrm{~m}$. Wind direction of stronger winds are mainly towards the NE (Figure 1d), resulting in a dominance of oblique onshore winds in the western tip of the island (first $4 \mathrm{~km}$ from the western border, roughly) and winds parallel to the coast in the remaining island. Beach widths vary between $100-400 \mathrm{~m}$ in the shoal attachment zone, and around 350 m outside the attachment zone. 
a.

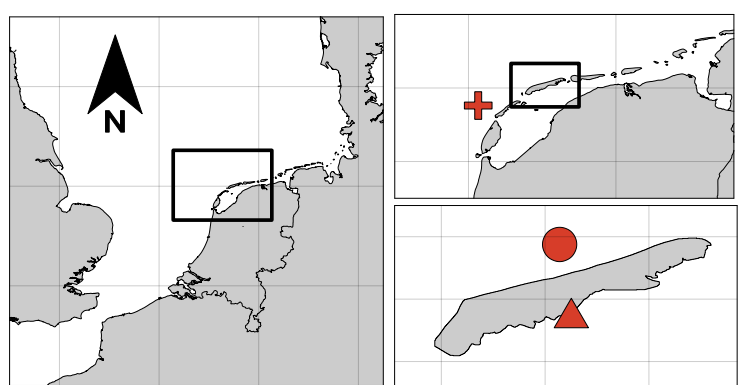

急

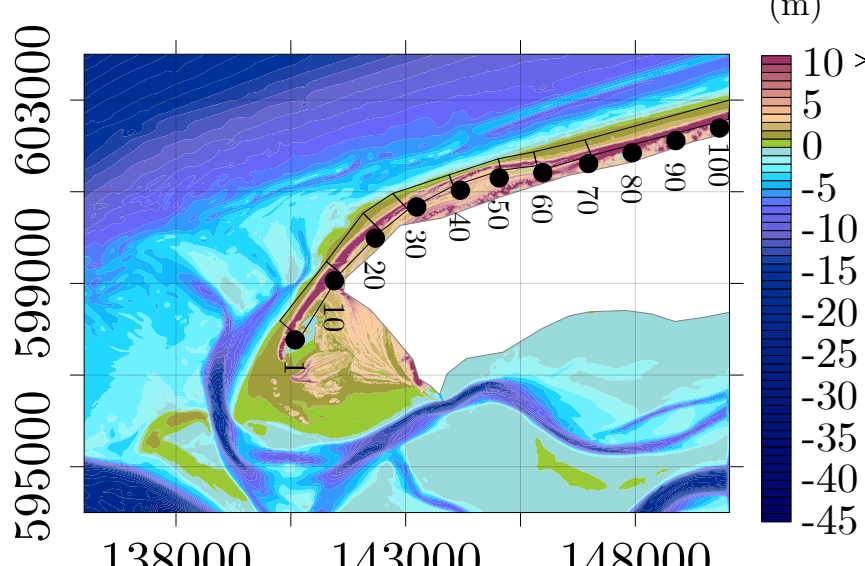

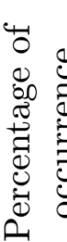

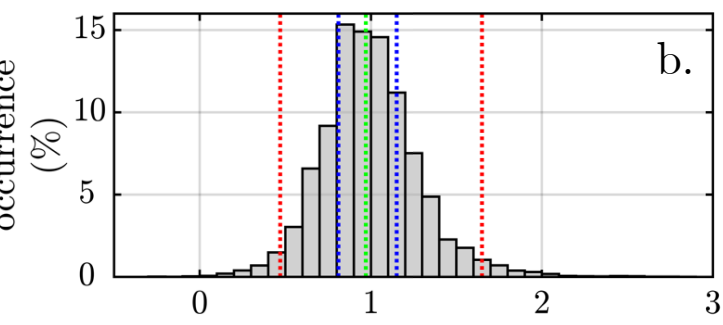

Daily maximum water level

$(\mathrm{m})$

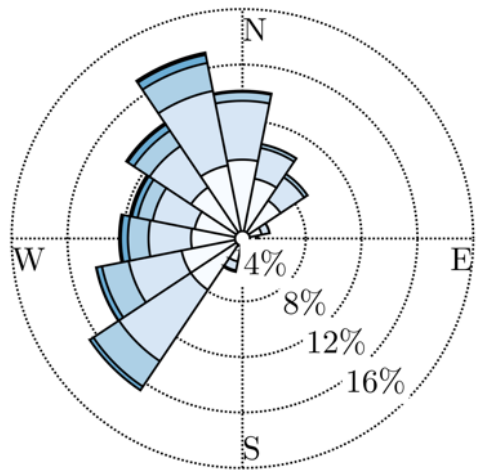

b.
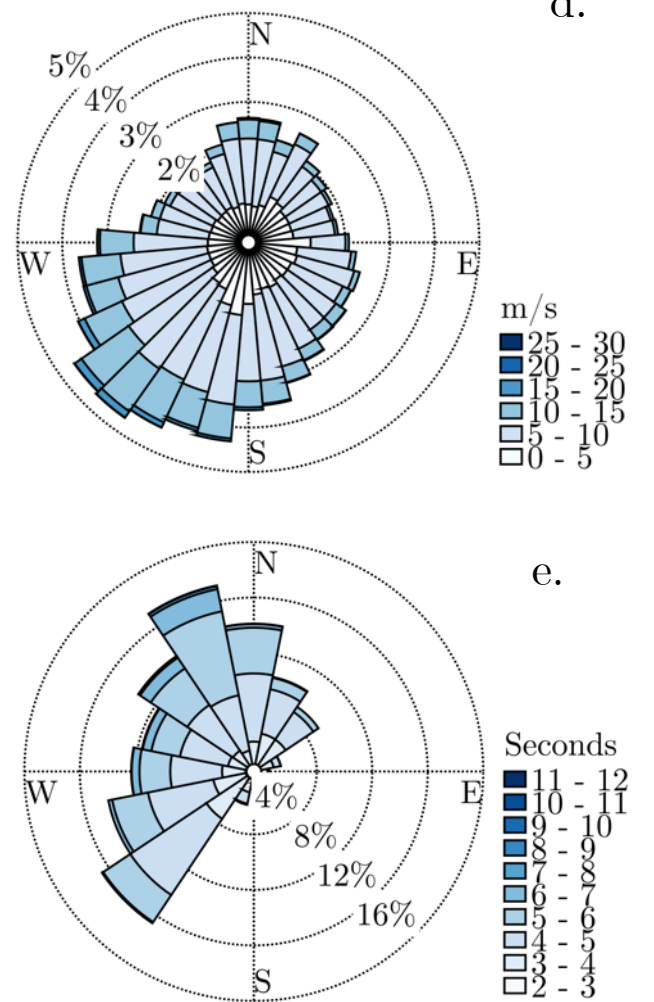

$\mathrm{RDx}(\mathrm{m})$

Figure 1. (a) The study area of Terschelling. Red symbols represent the locations of the wave buoy (cross), weather station (triangle) and tide gauge (circle). Maps are built using the RD (Rijks-Driehoek) metric coordinate system. (b) Histogram of the daily maximum water levels, with the green line representing the median, the blue lines representing the 25 and 75 quantiles, and the red lines the 2.5 and 97.5 limits. Values referred to the Normaal Amsterdams Peil (NAP) datum. (c) Directional histogram for $\mathrm{Hm} 0$, in meters. (d) Directional histogram for mean wind speed, in meters per second. (e) Directional histogram for Tm02, in seconds. 
On the west side, Terschelling is bordered by the Vlie inlet, which has a tidal prism of $934 \times 10^{6} \mathrm{~m}^{3}$ [35]. According to [35], shoals have a cycle frequency of approximately 16 years, with an average migration velocity of $212 \mathrm{~m} /$ year $( \pm 69)$. Furthermore, the author states that the longshore sediment transport on the coast is $4 \times 10^{5} \mathrm{~m}^{3} /$ year. Shoal length varies between $750-3000 \mathrm{~m}$, whereas shoal width varies between $400-1800 \mathrm{~m}$. Regarding beach states, a modally intermediate state beach, with the nearshore zone characterised by a multiple bar system, has been reported [34,36]. Furthermore, several vegetation species (e.g., Ammophila arenaria, Corynephorus canescens) have been reported in the area, though their spatial distributions vary according to the type of dune [37].

\section{Material and Methods}

To achieve our objective, we used information from both the analysis of long-term monitoring data and idealised numerical modelling. The monitoring data gives information not only on the past subtidal and subaerial morphodynamics, but also on patterns of beach-dune evolution that may be associated with the ebb-tidal delta dynamics. The idealised model gives information on the effect of a varying beach due to a sequence of different shoal attachment processes in a controlled environment. We chose such an approach to isolate the role of the ebb-tidal delta dynamics on dune growth from other processes that may also lead to changes (e.g., wind direction, grain-size variations). Even though some parameters are based on the island of Terschelling (e.g., initial beach width, shoal attachment period), the idea behind the modelling is to explore what would happen at the dunes if only specific conditions in cyclic beach width variations happened.

\subsection{Dataset and Analysis of Multi-Annual Monitoring Data}

Bathymetric data, with a resolution of $20 \times 20 \mathrm{~m}$ available for the years 1992, 1995, 1998, 2000, 2004, 2007, 2010, 2013 and 2016, was used to track shoal attachment periods, the location of attachment, and shoreline evolution forced by these subtidal processes. Vertical accuracy estimates of the bathymetric data range from 0.11 to $0.4 \mathrm{~m}[38,39]$. Also, we built an average annual difference map using yearly estimates of bathymetry. For each year, we calculated the changes in elevation and plotted the average of such a change. For such a map, linear interpolation in time was used to fill years without data. Furthermore, we used yearly LiDAR data available from 1997 up to 2017 to analyse beach width variability and dune growth. LiDAR data is available in a minimum spatial resolution of $5 \mathrm{~m}$, with a maximum resolution of $2 \mathrm{~m}$ from 2013 onward. Vertical accuracy estimates for the LiDAR data is around $0.15 \mathrm{~m}$ [40]. For consistency with the rest of the dataset, LiDAR data from 2013 onward were re-interpolated in a 5-m grid. From the LiDAR data, we extracted 100 cross-shore profiles, spaced approximately $100 \mathrm{~m}$ alongshore. The profiles were used to derive shoreline position, foredune position and dune volume. Shoreline position was defined by the location of the $0-\mathrm{m}$ contour. Foredune position and dune volume were calculated considering the dunefoot as the 3-m contour. The dunefoot level, along the Dutch coast, is widely assumed to be approximately $3 m+N A P$ (i.e., Normaal Amsterdams Peil-in Dutch—is the Dutch reference level, which is close to the mean sea level) $[7,8,41-46]$. The value is based on early measurements, in which dunefoot elevation was defined as a visible break in slope between beach and dune, resulting on a contour of roughly $3 m+N A P$ [44]. Thus, dune volume was calculated as the volume above the 3-m contour, and the dunefoot of the 3-m contour itself. Although common in The Netherlands, only one nourishment was registered in the area, dating back to 1993 and located east of the profile number 100. Annual changes in dune volume and shoreline position derived from the data needed to overcome potential measurement error. Based on [40], these errors were estimated to be $20 \mathrm{~m}^{3} / \mathrm{m}$ and $10 \mathrm{~m}$ for dune volume and shoreline change, respectively.

\subsection{The DUBEVEG Model}

The DUBEVEG model $[47,48]$ is a self-organising cellular automata model built to simulate dune development in the coastal land-water interface. It is based on the DECAL model [49-51] for inland 
dune development. The DUBEVEG model has been used to understand the long-term behaviour of beach-dune systems and their dynamics related to sea-level rise [48], beach width variability [7] and the influence of geological settings such as sand flats [11]. It has been successfully used in a wide range of areas where the main interest was to qualitatively understand how the interaction of different processes translates into patterns over a longer time span $[7,11,48,50-56]$. It includes a sediment transport module that mimics wind-driven sediment transport, hydrodynamic module and biotic processes related to vegetation. Sand transport, vegetation growth, and dune development are simulated by probabilistic rules that mimic crucial bio-physical feedback interactions for dune growth, development and decay. Given an initial topography $T$, displayed into grid cells in a 2D matrix, cells will re-adjust themselves within the grid, following probabilities of erosion and deposition. Probabilities are conditioned by characteristics of each cell node and their surrounding cells. Per iteration, a group of cells are chosen randomly to move in a pre-defined direction (i.e., mimicking the onshore aeolian sediment transport). The moving cells (i.e., sand slabs) are a square-shaped model representation of a standard volume of sand. The model does not explicitly use wind strength or shear stress, but instead simulates the sediment transport assuming that there is a certain probability that the slab will be transported at each time-step (in reality, whether wind threshold is achieved or not). The probability is based on ([51] Equation (3)), and may vary locally due to the presence of vegetation. There is no seasonality related to potential sediment transport applied, as well as variations in potential transport due to the wind direction. The groundwater level limits the vertical amount of slabs that are available for transport. Thus, changing groundwater levels to be closer or farther from the topographic surface controls sediment supply conditions, as shown by [11].

Sediment can be removed from or introduced in the domain through the hydrodynamic module. The model requires a conceptual equilibrium profile $(E p)$, which is a level that the topography returns to when affected by the hydrodynamic model. Thus, it may lead to either a positive (accretion) or negative (erosion) sediment balance at the beach. Therefore, the model assumes sufficient sediment being transported from the sea to maintain the beach position. The water level defines the portion of the beach profile that is affected by the hydrodynamic module. At each time step, the module calculates the maximum water level by selecting the highest water level in a two-week interval, plus an estimate wave run-up. Run-up estimates are based on empirical relations described in [57]. Whether or not a cell is eroded or accreted depends on a probability given to each inundated cell. This probability is a function of the presence of vegetation in the cell, plus the potential erosive strength of the waves. The model does not solve any wave transformation equations. Instead, waves are represented by a probability of erosion, which is maximum $(p=1)$ in the offshore, and reduce (i.e., representing wave energy dissipation) as an inverse function of the water depth. Inundated cells always have a small probability of erosion/accretion, regardless of the waves. Thus, dunes can be scarped and completely eroded, depending on the water level and the remaining wave energy in the adjacent cell. Regarding vegetation cover, the model accounts for two species: incipient and conservative vegetation, following the approach introduced by [51]. Further details on the model, such as sensitivity analysis and validation, can be found in $[7,11,48]$.

To address the effect of shoals on dune development, we adapted the model with an idealised representation of a shoal attachment process. It assumes that shoals reach the beach down-drift of the tidal inlet, supplying this beach with a fixed amount of sediment in a periodic process. For the present study, we use a shoal frequency of 15 years to match values found for Terschelling by [35]. When the shoals attach to the beach, we assume that it drives only shoreline changes. In the model, shoals land at one specific point alongshore. At this point, the coastline follows a sinusoidal behaviour in time, while the disturbance moves down-drift with a specific decay rate, with a solution of the form of:

$$
y_{k}(x, t)=A \times e^{-\sqrt{\frac{\omega}{2 a}} x} \times \cos (\omega t-k x)
$$


where $y_{k}$ represents the shoreline (i.e., $0-\mathrm{m}$ contour), $A$ is the initial amplitude of the shoreline disturbance, $e^{-f(x)}$ describes the decay as a function of the alongshore position $x$, and the cosine represents the progressive shoreline sand wave (Figure 2). The value chosen for $A$ is proportional to the wavelength, under the assumption that, qualitatively, both would be related to the size of the shoal (i.e., a bigger shoal would induce a greater amplitude and wavelength in the shoreline signal than a smaller shoal. A large increase in amplitude with a small wavelength would be unlikely). The value for the constant $a$ was chosen to keep the decay form inside our modelling domain throughout all the tested scenarios, while maintaining the magnitude within the order of magnitude found on similar processes (i.e., shoreline sandwaves). Also, we removed the negative component of the cosine function in the final shoreline model. The reason is based on the current lack of evidence to support the same erosive behaviour as found on shoreline sandwaves. In reality, changes in shoreline are likely to drive several changes on nearshore gradients that will lead to phases of erosion and accretion, which are not considered in our simplified shoreline model. Table 1 presents detailed information on the variables. The solution is based on (Equation (4), [58]) for shoreline sand waves and assuming a one-line coastline model:

$$
\frac{\partial y_{k}}{\partial t}-a \frac{\partial^{2} y_{k}}{\partial x^{2}}=0
$$

From the shoreline solution, we chose 20 positions alongshore spaced $100 \mathrm{~m}$ apart, from which we built full idealised cross-shore beach profiles. Each cross-shore profile was extrapolated alongshore in separate 2D domains. Then, each domain was used as the initial and equilibrium $(E p)$ topography in the model. Cross-shore profiles have an initial beach width (i.e., the distance between 3-m contour and 0 -m contour) of $100 \mathrm{~m}$, on which we added any cross-shore disturbance introduced by the attachment of the shoal. Moving the 0-m contour seaward or landward adds the cross-shore disturbance, following Equation (1). The new position of the 0 -m contour defines a new equilibrium beach profile (Ep), which is created by linear interpolation up to a pre-defined node (Figure 3). For the present study, we chose the fixed node as the 1-m contour, which roughly represents the mean spring high tide level. As the shoreline evolves in time, so does the equilibrium profile, introducing the new sediment balance from the shoal to each position alongshore. We chose such an approach since it is not the purpose of the model to simulate subtidal evolution, but rather subaerial evolution. Thus, the shape of the beach due to hydrodynamic forcing can be adjusted per-iteration without in-model calculations. The portion of the $E p$ above one meter was built manually using slope values of the upper beach common in the area. The subtidal part was built following [59].

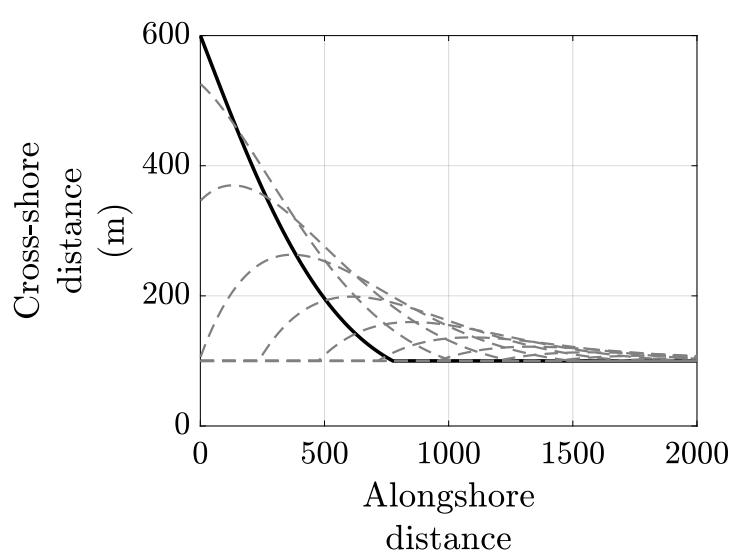

$(\mathrm{m})$

Figure 2. Example of shoreline movement based on Equation (1). The black line represents the initial shoreline position, followed by the grey-dashed lines as it moves into different stages in time. 


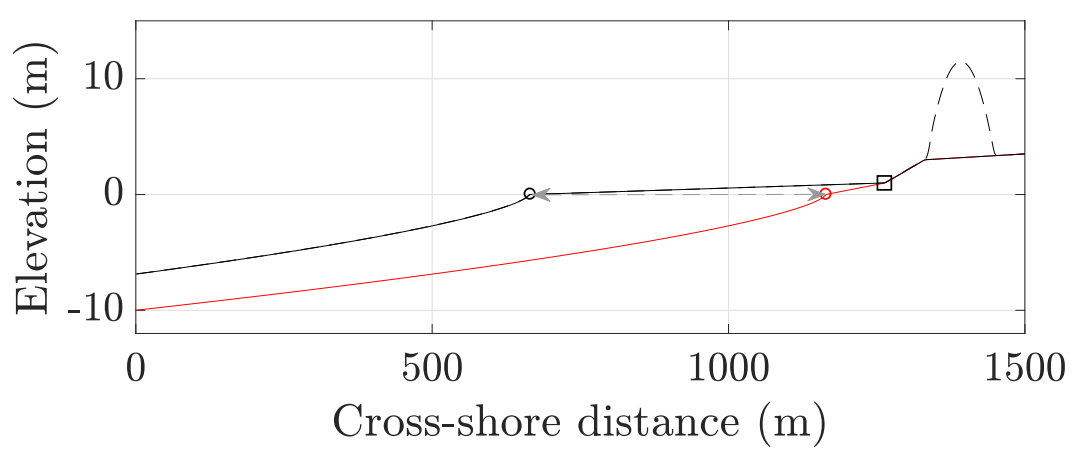

Figure 3. Example of beach width movement, highlighting the node points used to adjust the equilibrium profile in time. The red and the black line represent two different moments in time. Circles represent node points used to adjust beach width, whereas the black square represents the most landward node point where the shoal induces no change. Grey-dashed parabola represents a hypothetical foredune, for reference. Values below the 0-m contour are based on [59].

Table 1. Specific notations and functions used in the shoreline decay solution form.

\begin{tabular}{ccc}
\hline Name & Notation & Function/Value \\
\hline Amplitude $(\mathrm{m})$ & $\mathrm{A}$ & $\mathrm{L} / 6$ \\
Angular frequency $\left(\right.$ year $\left.^{-1}\right)$ & $\omega$ & $2 \pi / \mathrm{T}$ \\
Period (year) & $\mathrm{T}$ & 5 and 15 \\
Wave number $\left(\mathrm{m}^{-1}\right)$ & $\mathrm{k}$ & $2 \pi / \mathrm{L}$ \\
Wavelength $(\mathrm{m})$ & $\mathrm{L}$ & $250,500,1000,2000$ and 3000 \\
Constant & $\mathrm{a}$ & 10 \\
\hline
\end{tabular}

Two periods were tested (i.e., 5 and 15 years) regarding the progressive shoreline wave (which influences the rate of alongshore dispersion of the shoal). Periods have been chosen to ensure full dispersion of the previous shoal before the next attachment. Regarding the wavelength of the progressive wave (which influences the size of the shoal), five values were tested, all in meters: 250, 500, 1000, 2000, and 3000. Table 2 shows all tested scenarios. All simulations spanned 90 years, in which multiple shoal attachment events occurred, always assuming that there is sufficient feeding from the sea to maintain the equilibrium level. The simulation length was chosen to ensure multiple attachments and sufficient time to any adaptation on the beach-dune system to take place. In our case, where the cycle is 15 years, 90 years lead to six attachments in total and sufficient time for the beach-dune system to evolve. A water-level time-series, gathered from a nearby tide-gauge in the North Sea (Figure 1), was used as the boundary condition for all simulations. We performed simulations using two different sediment supply scenarios controlled by groundwater depth [11]. The groundwater was settled as a proportion of the $E p$, being 0.5 for the unlimited supply condition, and 0.8 for the limited supply condition. Further information on the groundwater assumptions within the model can be found in [11]. Besides beach width variability and potential supply due to groundwater depth, all other initial conditions are the same for all simulations. Dune volume and final foredune position were extracted from the simulations by the same methods used in the LiDAR data analysis. We performed five simulations for each combination of conditions, and used the average values. The number of simulations was chosen based on the Confidence Interval method [60,61], which aims at finding the number of replicates necessary to narrow the confidence interval up to a specified precision $d_{\text {min }}$, defined as half-width of the confidence interval in terms of percentage of the sample mean. Using five simulations yield precision values for dune volume and position in the order of $2-2.5 \%$, which is lower than the suggested threshold precision (i.e., $5 \%$ ). In total, we performed a total of 1000 simulations.

Simulated results were compared at different locations alongshore to investigate whether there is a spatial dependency in final dune morphology due to alongshore changes in shoreline behaviour. Spatial autocorrelation defined spatial dependency, whereas the non-parametric Wilcoxon rank-sum 
test defined statistical significance between attachment and non-attachment zones. Moreover, the total net potential hydrodynamic sediment supply was calculated for each scenario tested. The total net hydrodynamic sediment supply is the amount of sediment introduced by in-model calculations without considering accretion and erosion related to subtidal processes (i.e., excluding sedimentation associated with imposed shoreline changes).

Table 2. Summary of simulation scenarios based on shoreline disturbances characteristics.

\begin{tabular}{ccc}
\hline Simulation Letter & Period (years) & Wavelength (m) \\
\hline a. & 5 & 250 \\
b. & 15 & 250 \\
c. & 5 & 500 \\
d. & 15 & 500 \\
e. & 5 & 1000 \\
f. & 15 & 1000 \\
g. & 5 & 2000 \\
h. & 15 & 2000 \\
i. & 5 & 3000 \\
j. & 15 & 3000 \\
\hline
\end{tabular}

It is important to note that the primary purpose of the model is to be applied as an exploratory tool rather than a predictive tool. Despite recent advances, most cellular automata models are not meant to accurately reproduce real cases quantitatively due to the level of simplification and the hindrance of using validation tools that are commonly used in deterministic models [48]. However, it presents a smart bottom-up solution for complex systems, where simple interactive processes in the microscale could evolve into macroscale patterns. Thus, such models can be advantageous to understand how the interaction of different processes translates into patterns over a longer time span.

\section{Observed Effects of Shoal Attachment on Dunes}

\subsection{Subtidal Evolution}

Overall, bathymetric maps show five beach width change events associated to a shoal directly (i.e., attachment of the shoal) or indirectly (i.e., shoreline sheltering due to shoal) (Figures 4 and 5). Labels for each event are shown in Table 3 and used within the text. Direct changes due to shoal attachment (Events 1 and 2) happened between 1992 and 1998, approximately between profile 20 and 30, and between 2012 and 2016, between profiles 10 and 20 (Figure 6). Maximum values of change forced by the attachment increased the beach width by around $40 \%$, for event 1 , and $112 \%$ for event 2 . Interestingly, even though attachment produced on average an increase in beach width, there were some locations where erosion occurred, with values that reached a maximum of $18 \%$ and $53 \%$ of the average beach width for events 1 and 2, respectively. Nevertheless, average and median values show that an overall increase of beach width took place due to the attachment. 


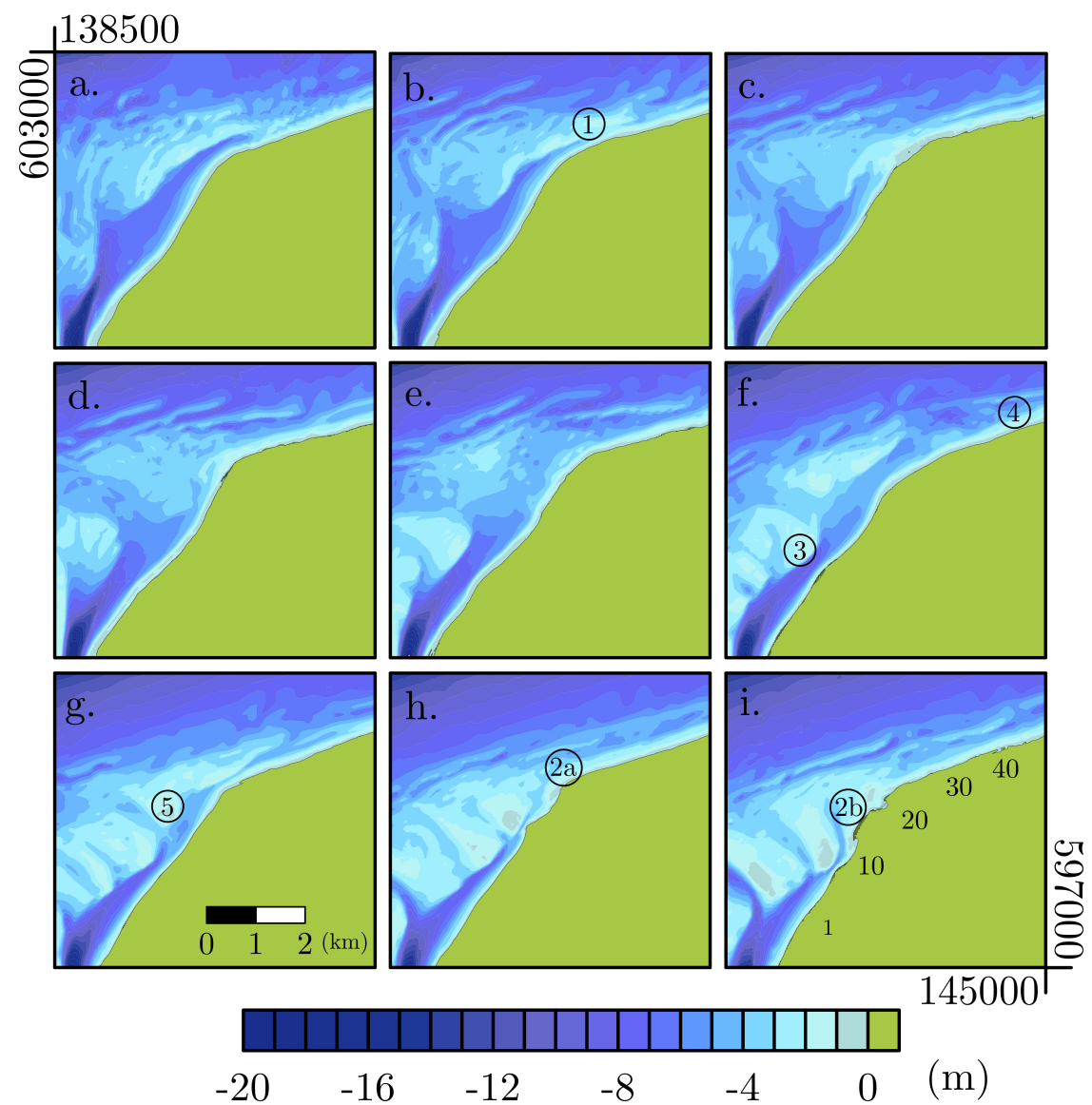

Figure 4. Bathymetric maps from 1992 (a), 1995 (b), 1998 (c), 2000 (d), 2004 (e), 2007 (f), 2010 (g), 2013 (h) and 2016 (i). Numbers without a circle show the approximate location of the profiles, whereas numbers with a circle relate to the shoal events in Table 3.

Even though shoals caused an increase in beach width, the coast presents an overall erosive trend, with values in the order of $-1 \mathrm{~m}$ per year when accounting for the total change over the period. Furthermore, even though shoals are capable of increasing the beach, the total increase of beach width is already spread over the coast after a period shorter than the average shoal attachment period, which is approximately 15 years. For shoal 1, the total average increase of beach width was on the order of $90 \mathrm{~m}$ between 1997-1999. This increase of beach width is eroded after five years, whereas for shoal 2a, the total average increase ( $40 \mathrm{~m}$, approximately) was eroded after two years.

Shoal events 3 to 5 (Table 3) yield a lower average beach width increase than shoal events 1 and 2 . On average, events 3 to 5 presented increases of $13 \mathrm{~m}$ per year, whereas events 1 and 2 resulted in an average beach width increase of $40 \mathrm{~m}$. Even though the average amount of beach width increase was smaller than events 1 and 2, the shoal 3 was still able to increase a total amount of around $100 \mathrm{~m}$ from 2000 up to 2007, which is around $44 \%$ of the average beach width between profiles 1-10.

The average annual difference map shows an erosive trend in the channel south of profile 1-10 and an accretion trend on the ebb-tidal area (Figure 7). Interestingly, values between $\pm 0.25 \mathrm{~m}$ per year dominate the region between profile $30-50$, suggesting that the average variability of this region is small and, in some areas, within the measurement error. Values are also lower from profile number 50 up to 100, suggesting less shoreline variability north of profile 50 . Shoreline change statistics also show higher variability in the western profiles, as expressed in higher values of standard deviation. From those, the stretch between profiles 11-30 is the most variable (Table 4). 


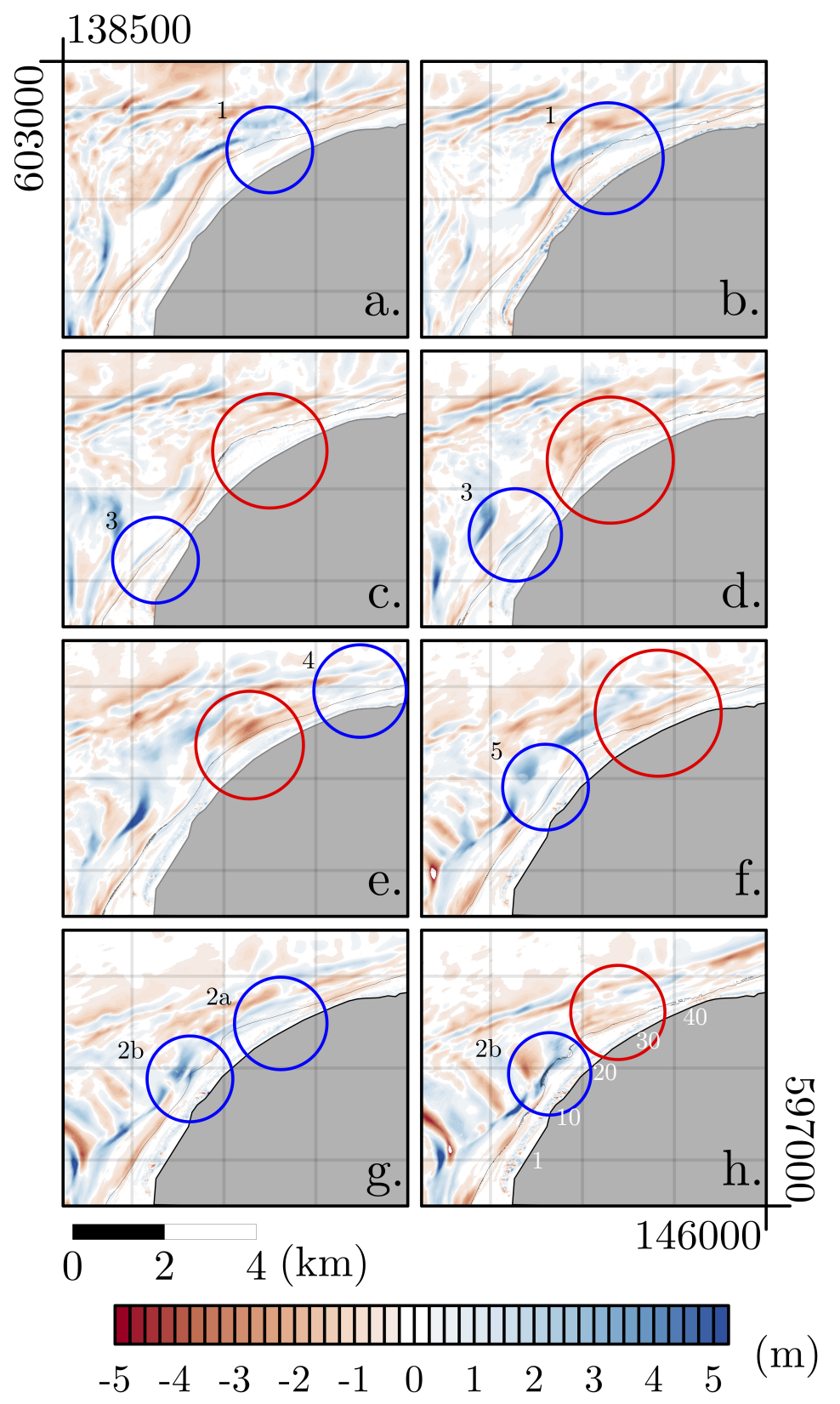

Figure 5. Bathymetric difference maps for periods between 1992-1995 (a), 1995-1998 (b), 1998-2000 (c), 2000-2004 (d), 2004-2007 (e), 2007-2010 (f), 2010-2013 (g), 2013-2016 (h). Blue and red circles highlight phases of shoreline accretion and erosion. 

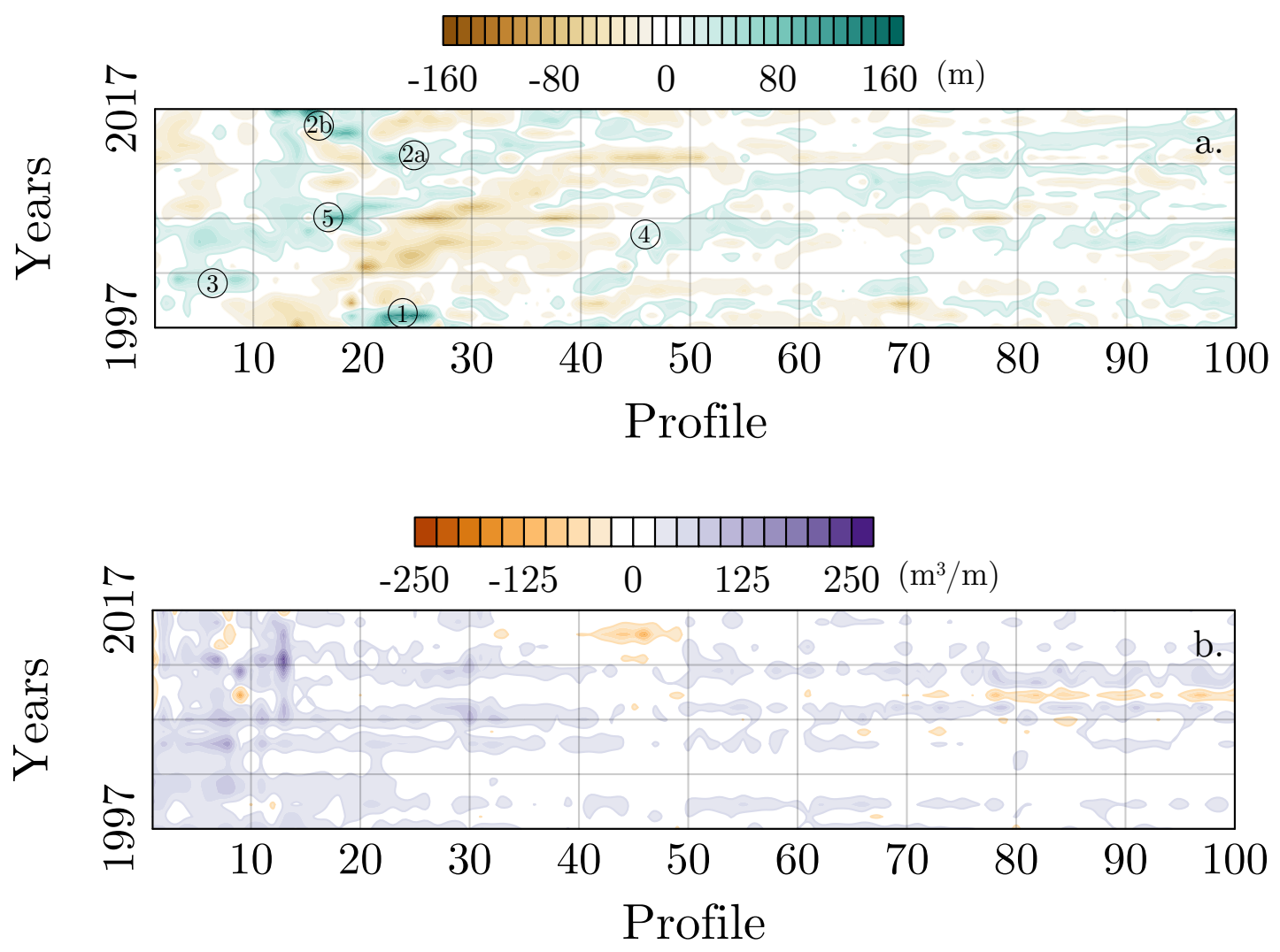

Figure 6. (a) Beach width changes based on LIDAR data between 1997 and 2017. Y-axis represents time, in years, whereas $X$-axis represents the profiles alongshore. Numbers inside the figure relates to the shoal events. (b) Dune volume changes based on LIDAR data between 1997 and 2017. Y-axis represents time, in years, whereas $X$-axis represents the profiles alongshore.

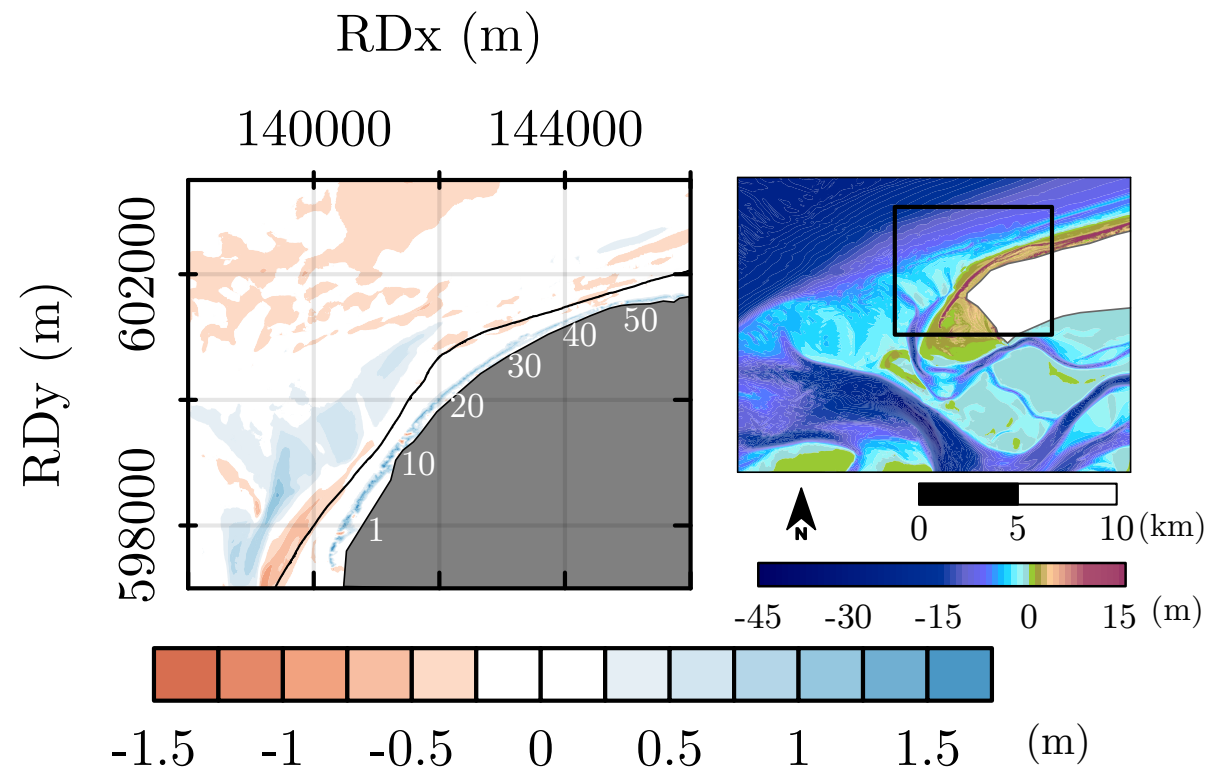

Figure 7. Average annual difference map (left) based on the yearly changes extracted from the bathymetric data. Solid black line represents the $0-\mathrm{m}$ contour. White numbers represent approximate locations of the profiles. Topography inset from 2016. 
Table 3. Statistics for shoreline change related to each handpicked shoal.

\begin{tabular}{|c|c|c|c|c|c|c|c|c|c|c|c|}
\hline \multirow{2}{*}{ Year } & \multirow{2}{*}{ Shoal/Event Number } & \multirow{2}{*}{ Profiles } & \multicolumn{9}{|c|}{ Shoreline Change (m/year) } \\
\hline & & & Mean & Median & Standard Deviation & Min & Year (Min) & Max & Year (Max) & 25th Percentile & 75th Percentile \\
\hline 1997-1999 & 1 & $21-30$ & 43.2 & 36.4 & 64.7 & -71.4 & 1997-1998 & 159.4 & 1998-1999 & -2.6 & 83.5 \\
\hline $2011-2013$ & $2 a$ & $21-30$ & 20.0 & 16.8 & 19.2 & -9.0 & $2012-2013$ & 63.5 & $2011-2012$ & 6.7 & 31.0 \\
\hline $2016-2017$ & $2 b$ & $11-20$ & 58.9 & 54.6 & 138.7 & -140.4 & $2016-2017$ & 291.9 & $2016-2017$ & -28.7 & 134.8 \\
\hline 2000-2007 & 3 & $1-10$ & 14.1 & 12.2 & 19.9 & -22.6 & $2006-2007$ & 71.6 & $2001-2002$ & 0.0 & 24.4 \\
\hline 2004-2007 & 4 & $41-50$ & 2.5 & 0.0 & 20.6 & -39.3 & 2006-2007 & 37.9 & 2004-2005 & -8.7 & 19.5 \\
\hline 2005-2010 & 5 & $11-20$ & 17.1 & 17.0 & 32.1 & -59.4 & 2009-2010 & 107.9 & 2006-2007 & 0.1 & 30.5 \\
\hline
\end{tabular}

Table 4. Alongshore variation in shoreline position statistics between 1997 and 2017.

\begin{tabular}{cccccccccc}
\hline Profiles & $\begin{array}{c}\text { Mean } \\
(\mathbf{m})\end{array}$ & $\begin{array}{c}\text { Median } \\
(\mathbf{m})\end{array}$ & $\begin{array}{c}\text { Standard Deviation } \\
(\mathbf{m})\end{array}$ & $\begin{array}{c}\text { Min } \\
(\mathbf{m})\end{array}$ & $\begin{array}{c}\text { Year } \\
\mathbf{( M i n})\end{array}$ & $\begin{array}{c}\text { Max } \\
(\mathbf{m})\end{array}$ & $\begin{array}{c}\text { Year } \\
(\mathbf{M a x})\end{array}$ & $\begin{array}{c}\text { 25th Percentile } \\
(\mathbf{m})\end{array}$ & $\begin{array}{c}\text { 75th Percentile } \\
(\mathbf{m})\end{array}$ \\
\hline $1-10$ & -0.4 & -1.3 & 22.8 & -48.8 & 2012 & 152.6 & 2017 & -12.2 & 8.7 \\
$11-20$ & 7.5 & 1.9 & 49.2 & -140.4 & 2017 & 291.9 & 2017 & -16.2 & 24.6 \\
$21-30$ & -8.1 & -11.2 & 40.1 & -95.2 & 2007 & 159.4 & 1999 & -31.9 & 12.7 \\
$31-40$ & -9.0 & -11.2 & 23.9 & -77.1 & 2007 & 50.5 & 2015 & -22.4 & 5.6 \\
$41-50$ & -3.5 & 0.0 & 24.9 & -73.0 & 2012 & 84.2 & 2017 & -18.9 & 13.1 \\
$51-60$ & -2.4 & -5.0 & 17.9 & -65.4 & 2012 & 40.2 & 2010 & -15.1 & 5.0 \\
$61-70$ & -0.9 & 0.0 & 18.4 & -77.6 & 2000 & 51.8 & 2010 & -12.6 & 10.1 \\
$71-80$ & 0.3 & 0.0 & 17.4 & -58.0 & 2007 & 38.6 & 2010 & -8.5 & 12.2 \\
$81-90$ & 0.9 & 0.0 & 15.5 & -36.7 & 2008 & 41.4 & 2005 & -10.4 & 13.7 \\
$91-100$ & 3.6 & 5.1 & 18.4 & -38.6 & 2015 & 63.0 & 2006 & -9.7 & 15.5 \\
\hline
\end{tabular}




\subsection{Relation between Beach Width and Dune Development}

Using information gathered on the effects of shoal/ebb-tidal dynamics on beach width, two distinct zones of potential influence on dune growth were defined: one between profiles 1-50, which is controlled by ebb-tidal delta dynamics (i.e., affected by shoal attachment, channel migration), and another between profiles 51-100.

The beach-dune system along the island exhibits high morphological alongshore variability. Regarding morphology, dunes outside the shoal attachment zone tend to exhibit a prograding behaviour, with new foredune development in front of the existing foredune (Figure 8). On the other hand, the dunes between profiles 1-30 were mostly single crested and dune volume growth generally involved heightening of this crest. Furthermore, dunes tend to be higher between profiles 1-30 (Figure 9). Dune volumes follow the same pattern, where average values are higher in those zones. The variability of both volume and maximum dune height is also higher between profiles 1-30. The beach width presents a much higher variability between profiles 1-50 than 51-100, achieving maximum values between profiles 20-40. Median values of beach width also present a higher range between profiles 1-50 than profiles 51-100. The average azimuth presents a gentle change from 300 degrees until around 355 from profiles 1-30.

Regarding volume estimates, results show that the first zone presents higher average values of dune volume per longshore component, with values of $1329 \mathrm{~m}^{3} / \mathrm{m}( \pm 784)$ and $1253 \mathrm{~m}^{3} / \mathrm{m}$ $( \pm 440)$, respectively. However, when considering only the profiles between 1-30, the average value is $1821 \mathrm{~m}^{3} / \mathrm{m}( \pm 636)$. Furthermore, a Wilcoxon rank-sum test shows that the two zones are statistically different $(p<0.05)$ in terms of annual dune volume change per longshore distance (Table 5). The significant difference is due to the increased values between profiles 1-30, and not necessarily related to the ebb-tidal dynamics (Figure 10). A significant $(p<0.05)$, but weak, negative correlation $(R=-0.16)$ exists between individual azimuth and volume changes. When using time-averaged values to minimise the effect of inter-annual variability, the correlation becomes stronger $(R=-0.59)$, suggesting a dependency on the azimuth on the potential amount of supply to the dunes. In time, both zones exhibited steady growth in terms of volume. In terms of area, a higher rate of change occurs between the years 2002 and 2006 at the area outside the shoal attachment zone, which represents an expansion of the dune field. No peaks or cycle patterns that could be related to beach width changes seem to occur.

Therefore, subaerial dune development over the period presents two main characteristics: instant change in beach width does not translate into dune volume change; western profiles present a higher rate of change than the remaining part of the coastline.

Table 5. Non-parametric statistical significance test (i.e., Wilcoxon rank-sum test) of alongshore differences in annual dune volume change.

\begin{tabular}{ccccccc}
\hline Profiles & Median $\left(\mathbf{m}^{\mathbf{3}} / \mathbf{m}\right)$ & 25th Quantile & 75th Quantile & Zval & Rank-Sum & $p$ \\
\hline $1-50$ & 20.2 & 6.7 & 39.2 & 8.8 & $1,113,704$ & $p<0.001$ \\
$51-100$ & 10.7 & 2.6 & 23.9 & - & - & - \\
& & & & & & \\
$1-30$ & 28.6 & 12.6 & 47.0 & 13.1 & 598,151 & $p<0.001$ \\
$51-100$ & 10.7 & 2.6 & 23.9 & - & - & - \\
$31-50$ & 12.8 & -0.1 & 22.6 & -0.7 & 275,553 & 0.49 \\
$51-100$ & 10.7 & 2.6 & 23.9 & - & - & - \\
\hline
\end{tabular}


Years
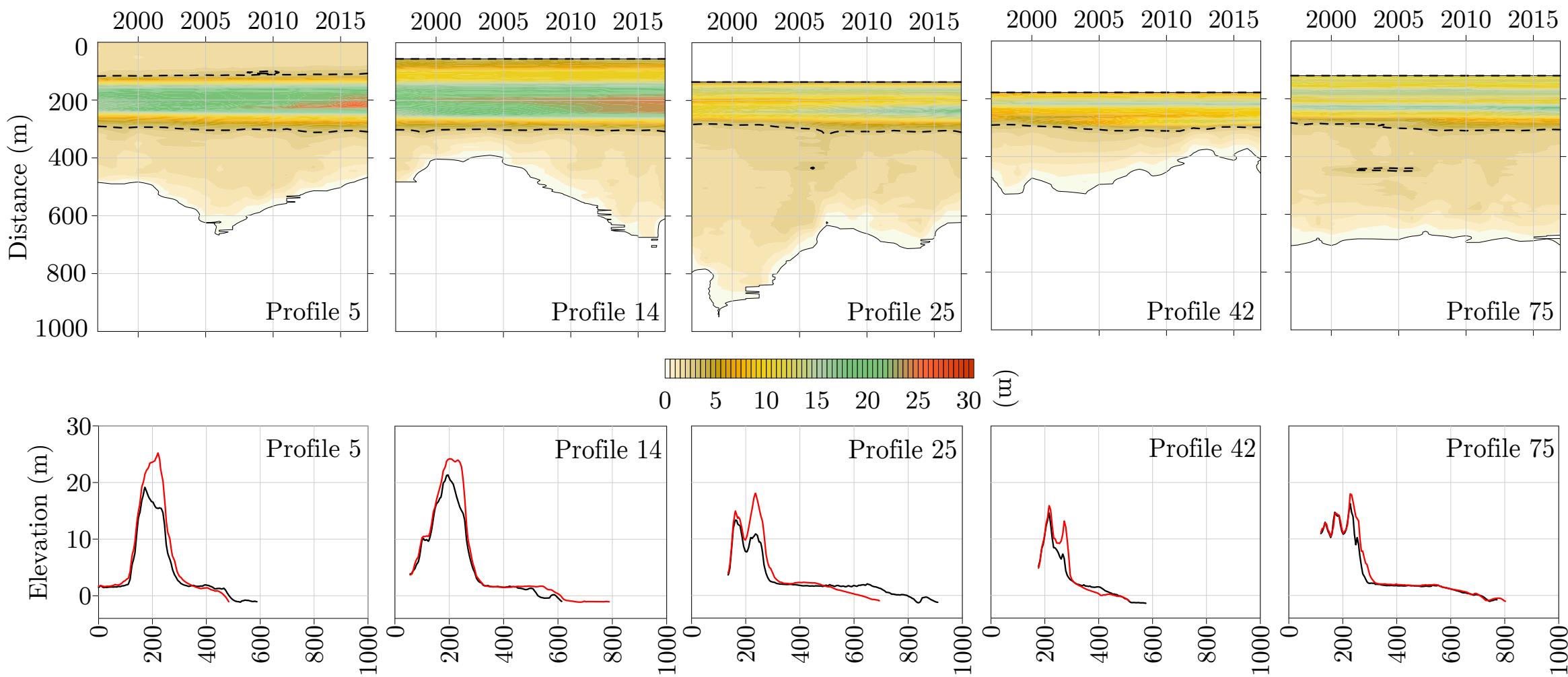

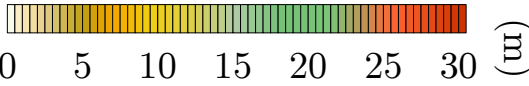

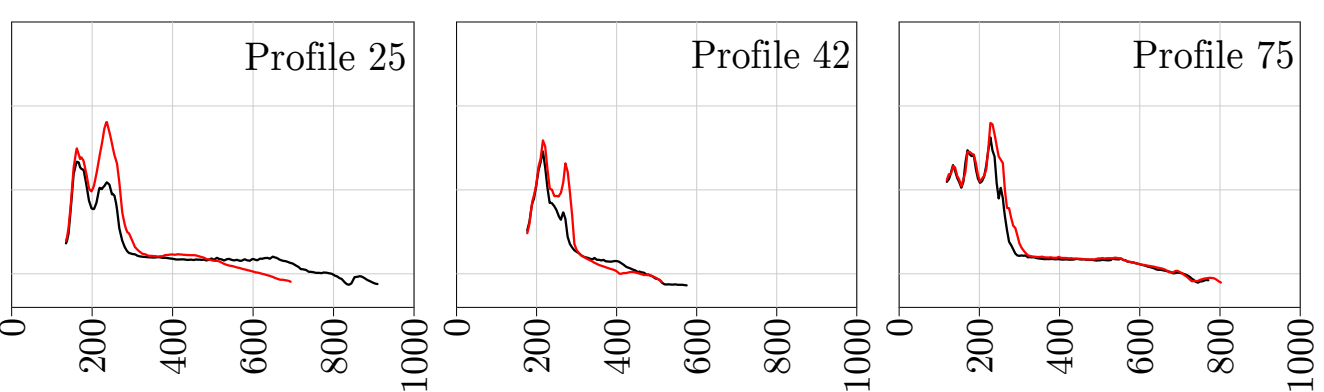

Distance $(\mathrm{m})$

Figure 8. Upper panels: Elevation evolution in time of five different profiles alongshore, with cross-shore distance on the $y$-axis and time, in years, in the $x$-axis. Lower panels: Final elevation differences for five different profiles. Dashed lines represent the 3-m contour. Black lines $=1997$ profile, red line $=2017$ profile. 


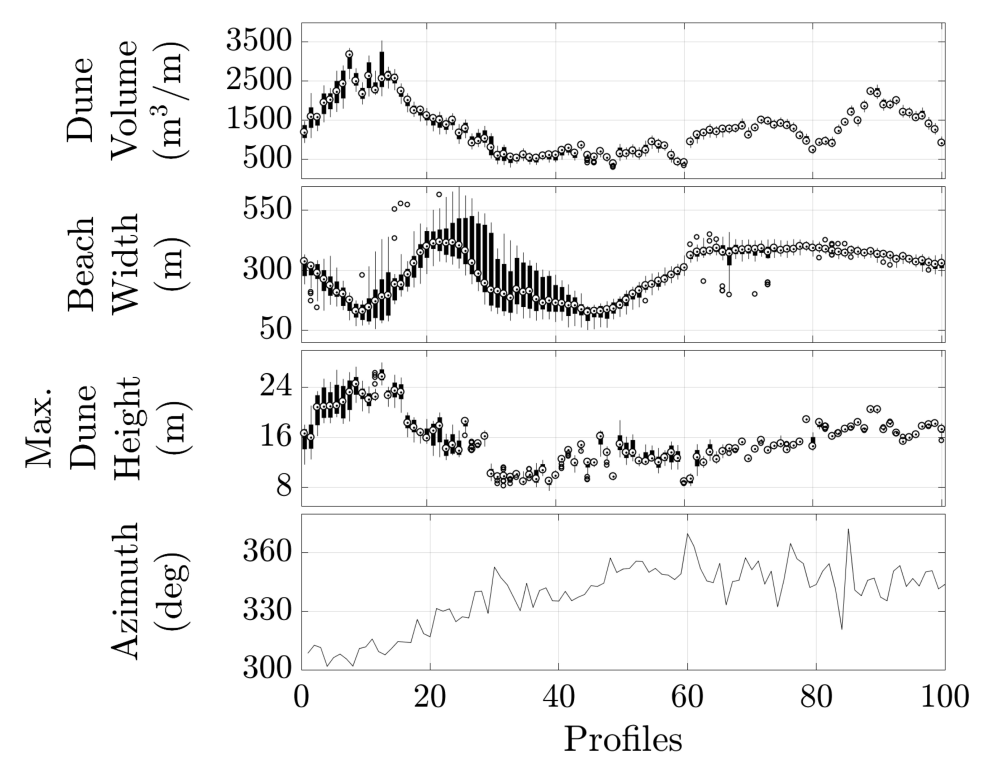

Figure 9. Boxplots of the morphological data alongshore extracted from the LiDAR data. The plotted azimuth refers to the average in time of each profile location.
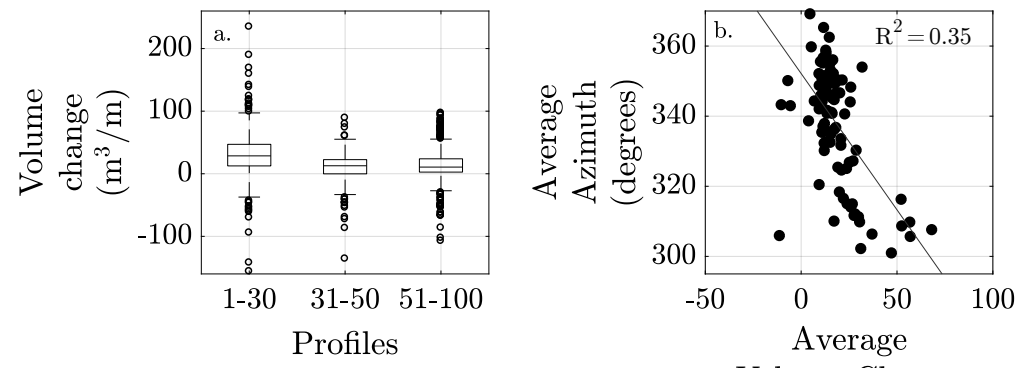

Volume Change $\left(\mathrm{m}^{3} / \mathrm{m}\right)$

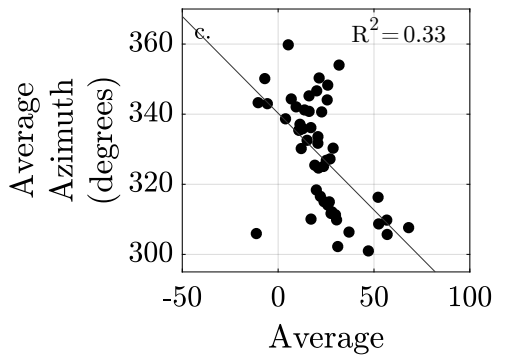

Volume Change $\left(\mathrm{m}^{3} / \mathrm{m}\right)$

Figure 10. (a) Boxplot of the annual dune volume changes separating three groupings of profiles. (b) Scatter plot of the average profile azimuth and dune volume change for profiles 1-100. (c) Scatter plot of the average profile azimuth and dune volume change for profiles 1-50.

\section{Modelling Results}

Results (Figure 11) show that, for a shoreline wave period of five years, higher shoreline variability in the western side did not translate into larger dune volume. On the other hand, for shoreline periods of 15 years, western sectors presented higher final dune volumes than the eastern sector for a wavelength of 1000, 2000 and $3000 \mathrm{~m}$. Spatial autocorrelation shows persistence in correlation values for these three scenarios, suggesting a spatial dependency for dune volume for these three cases, which is confirmed by using Wilcoxon rank-sum tests between both areas (Table 6). No persistence occurred in other scenarios. Similar spatial patterns happen for both unlimited and limited supply conditions. However, simulations with unlimited supply conditions resulted in larger dunes (i.e., $14 \mathrm{~m}^{3} / \mathrm{m}( \pm 2.9)$ larger than dunes on limited supply conditions).

Regarding beach width, final results show beach width between 100 and $110 \mathrm{~m}$ for all shoreline scenarios, with no apparent spatial trend alongshore. Correlation analysis shows no spatial dependency on beach width for both unlimited and limited supply scenarios. Morphologically, dunes remain mostly as a foredune after a 90-year simulation, with seldom occurrence of incipient dunes in front of it. The main differences are in the dune height, which follows the spatial pattern presented in the dune volume. 


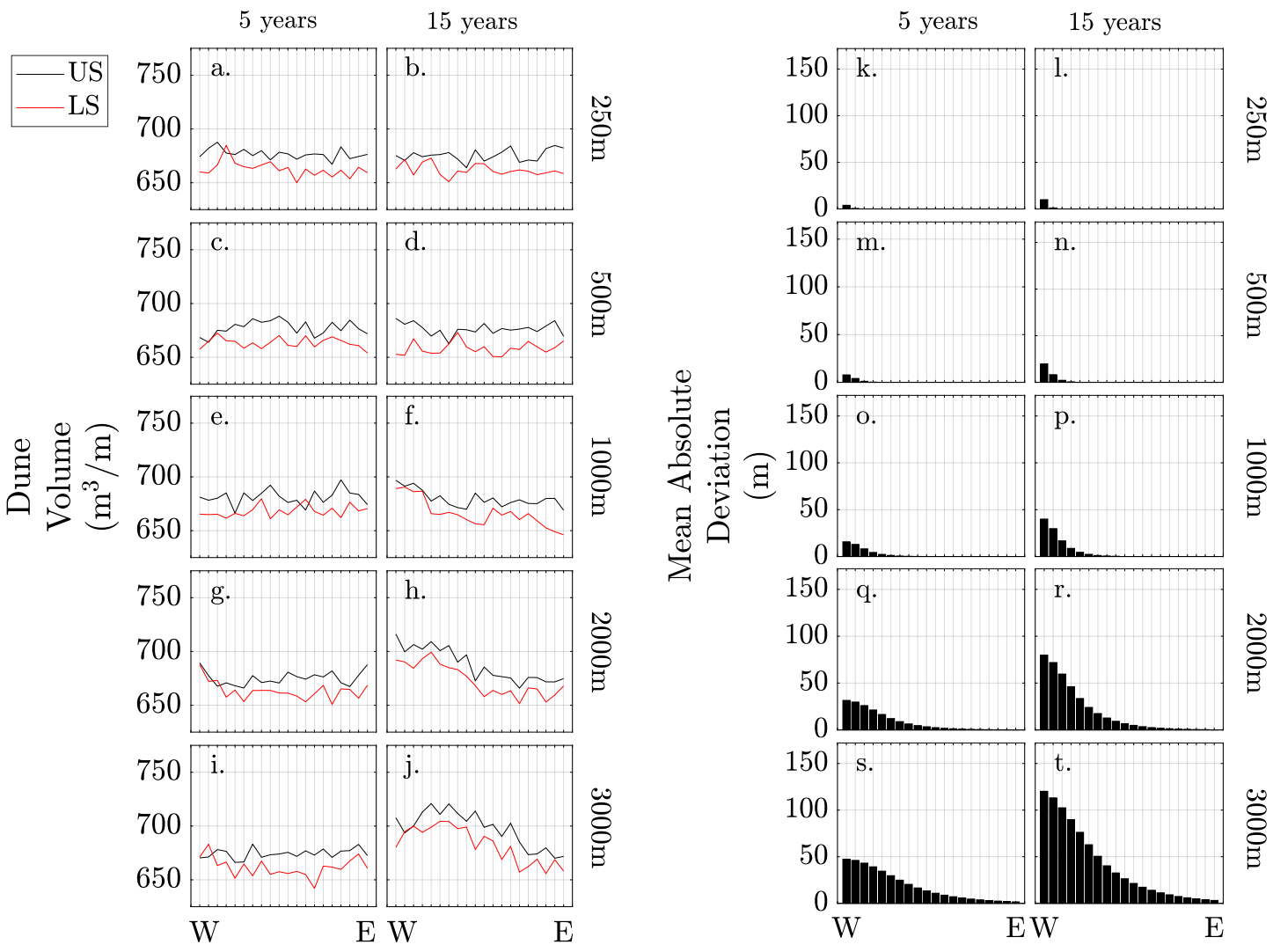

Figure 11. Dune volume estimates (a-j) and Mean Absolute Deviation from the shoreline position $(\mathbf{k}-\mathbf{t})$ based on numerical simulations. Letters represent the shoreline movement shown in Table 2. For the dune volume, black lines represent unlimited supply scenarios, whereas red lines represent a limited supply scenario.

Table 6. Wilcoxon rank-sum test results comparing dune volume from attachment and non-attachment zones for the modelled scenarios where a persistence, defined by autocorrelation, occurred.

\begin{tabular}{|c|c|c|c|c|c|c|c|c|c|c|}
\hline \multirow{3}{*}{ Scenario } & \multirow{3}{*}{ Persistence (m) } & \multicolumn{6}{|c|}{ Volume $\left(\mathrm{m}^{3}\right)$} & \multicolumn{3}{|c|}{ Wilcoxon Rank-Sum Test } \\
\hline & & \multicolumn{3}{|c|}{$\begin{array}{l}\text { Within } \\
\text { Zone }\end{array}$} & \multicolumn{3}{|c|}{$\begin{array}{c}\text { Outside } \\
\text { Zone }\end{array}$} & \multirow[t]{2}{*}{$p$} & \multirow[t]{2}{*}{ Zval } & \multirow[t]{2}{*}{ Ranksum } \\
\hline & & Median & 25th & 75th & Median & 25th & 75th & & & \\
\hline f. & 400 & 693 & 689 & 695 & 676 & 673 & 680 & 0.003 & 3.0 & 74 \\
\hline h. & 800 & 704 & 700 & 708 & 676 & 672 & 677 & $p<0.001$ & 3.6 & 131 \\
\hline $\mathrm{j}$. & 800 & 711 & 704 & 717 & 688 & 674 & 702 & 0.008 & 2.7 & 119 \\
\hline
\end{tabular}

The difference between shoals that induce a significant increase in dune growth and those which do not, is in the potential increase of supply that the shoal can introduce. Figure 12a shows the relation between total hydrodynamic sediment supply and dune volume. Figure $12 \mathrm{~b}$ shows the comparison between the percentage of potential supply increase due to shoal attachment processes (i.e., potential supply is the sum of supply before the shoal plus supply introduced by the shoal) compared to areas where no beach width change occurred (i.e., general potential supply related to a static beach width). Notwithstanding that, for all scenarios, hydrodynamic supply controls dune growth (Figure 12a), shoals must be able to increase the potential sea supply by a certain point to induce the development of significantly larger dunes. Based on Figure $12 b$, it is possible to define three different possible outcomes related to potential supply increase, due to the shoal attachment, and final dune volume. One outcome is related to shoals that add an increase in supply that is not 
sufficient to induce significantly larger dunes (zone clustered on the black symbols, between potential supply increase of $100-102 \%$, approximately). The second is the zone where the increase in supply is sufficient to induce larger dunes (zone clustered on the red symbols, where potential supply increase exceeds $105 \%$ ). The last one relates to scenarios where supply may or may not be sufficiently large to induce this growth (the area where black and red symbols are clustered together, approximately where potential supply increase is between 102-105\%). Relating the potential of significantly increasing dune growth to hydrodynamic supply suggests that scenarios, where simulations did not yield significant larger dunes, may require more time to reach sufficient cumulative supply levels to influence dune growth significantly.

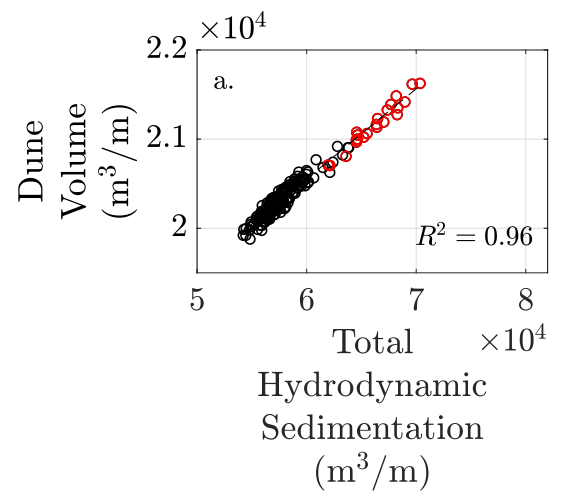

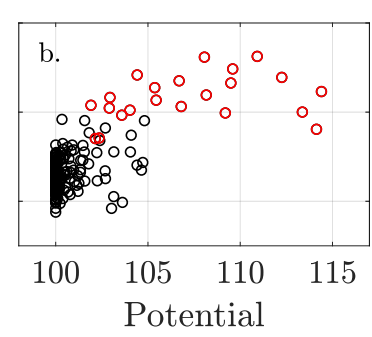

Supply Increase

$(\%)$

Figure 12. (a) Scatter plot of final dune volumes against total net hydrodynamic sedimentation. Red symbols represent data from model results that yielded significantly larger dunes $(p<0.05)$ than regions not associated with shoals, whereas black symbols represent data from profiles without final larger dunes. (b) Scatter plot of final dune volumes against cumulative potential supply increase induced by shoreline movements. Increases in supply are defined relative to the supply in profiles without the influence of a shoal as the reference (i.e., 100\% of supply). Red symbols represent data from model results that yielded significantly larger dunes than regions not associated with shoals, whereas black symbols represent data from profiles without final larger dunes.

\section{Discussion}

The results highlight two main findings: (1) beach width change due to the attachment of the shoals did not translate into a significant increase in dune volume in both short and long-term time-scales, and (2) the occurrence of a local increase in dune growth due to shoal attachment is, in the long-term, closely related to the size and extent of the shoreline change signal introduced by the shoal, suggesting a potential threshold increase for a noticeable influence at the dunes.

The analysis of the bathymetric data shows that a shoal is capable of increasing beach width directly, by attachment, or indirectly, by creating a shadow zone to the coast. Increasing beach width, in theory, leads to an increased space for dune development, increased potential supply, and increased dune protection against wave attacks due to the increased potential for wave dissipation $[9,12,62,63]$. The authors of [12] show that beach width influences the total volume of sand transported towards the dunes on an annual basis. Moreover, the authors of [12] argue that over periods of months to years, potential sediment supply to the dunes will vary directly with the beach width. Our results for Terschelling suggest that, even though shoals induce beach width change, sediment from individual shoals are redistributed alongshore before being able to increase dune volume significantly. Although the increase in beach width would be expected to lead to higher wave protection and more abundant aeolian sand supply to the dunes, no signal in dune volume occurred. Monthly to yearly signals in dune growth due to beach width increase require an in-phase synchronisation of onshore wind and proper beach surface conditions (e.g., surface moisture, grain-size characteristics, shell pavements) with the attachment [64]. Furthermore, local characteristics, such as beach orientation relative to main wind direction, rainfall and surface moisture, may also affect the potential of beach 
width to affect dune growth significantly. In [7], the authors show that limiting supply factors may reduce the capacity of beach width increase to affect dune growth. Also, it is crucial to consider the relaxation time expected for a morphodynamic system to adapt and lead to any positive or negative significant change [65-68].

Another factor that may influence whether beach width increase is reflected in dune morphology, is the initial beach width. Contrary to the shoals in Terschelling, the authors of [8] found that shoreline sandwaves, which change beach width, leave a signal at the dunefoot alongshore, with non-uniform dunefoot behaviour accounting for at least $80 \%$ of the residual variability of the dunefoot. One possible explanation could be related to the initial beach width on which the sandwave propagates or the shoal attaches. For wide beaches, the induced increase of supply and space might not be significant due to the already sufficiently large beach width (i.e., Available Fetch $>$ Critical Fetch). In contrast, small variations in narrow beaches (Available Fetch $<$ Critical Fetch) would lead to a significant increase in source width and, therefore, potential sediment supply. Moreover, the authors of [8] deal with an isotropic situation, on which the signal propagates equally alongshore, leading to similar beach width variability regardless of the alongshore position. In contrast, for shoals, the attachment zone would experience higher variability in beach width than locations not directly affected by the shoal attachment. Thus, the rate of dispersion may be a determining factor as to whether dunes would or would not have time to expand with the local increase in beach width.

Previous studies show that the welding of intertidal bars is a crucial process for sediment exchange between subtidal and subaerial beach profiles [69-71]. What could then explain the observed lack of signal in the dune volume and position in response to shoal attachment? Our modelling results suggest that shoal type (size and volume) and consequently how it changes beach width, has different outcomes in terms of dune evolution. Modelling results show that a higher dune volume is expected only for shoals that increase beach width considerably and that have a slow rate of dispersion. A small beach width increase with a fast longshore redistribution would translate into an increase of potential sediment supply that might be too small compared to other boundary conditions (e.g., overall aeolian transport of hydrodynamic erosive processes) to leave a signal in the foredune even on a long time-scale. Although even a small beach width increase would translate in a higher potential supply toward the dune [70], our results suggest that the scale of change should be larger, or of the same order of magnitude, than current supply to be translated into significantly different dune growth. Also, local conditions may induce local differences in the required duration and magnitude of ebb-tidal driven shoreline changes to leave a footprint at the dunes. Areas where local conditions may enhance the potential for sand to be transported by wind (e.g., beach orientation, wind direction, deep groundwater levels), may need less time or beach width increase for shoals to induce a significant increase in dune growth.

Although variations in beach width did not translate into a significant change in dune volume or position, long-term processes related to the ebb-tidal delta may shape the adjacent coastline in such a way that this may stimulate aeolian sediment transport. The authors of [35] show that ebb-tidal delta processes are responsible for the shape of the adjacent coastline of the Vlie Inlet. Our results show that such alongshore azimuth variability increases the potential of aeolian sediment transport between profiles 1-30, explaining the higher dunes and yearly sediment input due to the beach orientation relative to main wind transport, following the synchronisation concept proposed by [64].

Foredunes on barrier islands are generally not alongshore uniform, though the cause is still uncertain [10,72-74]. Our results suggest that ebb-tidal delta processes may lead to alongshore variations that affect foredune morphology. Uniformity of foredunes in barrier islands depends on several conditions, such as beach width, wind conditions and transport limiting factors. For a much longer time-scale, the authors of [75] show that inlet-driven processes may indeed induce beach-dune asymmetries near inlets. In [75], they show that relict paleo-channels may lead to a geologic framework that induces to asymmetric development of the beach-dune system up-drift of the paleo-channel due 
to channel infilling and longshore gradients. The authors argue that the scale of the asymmetry is related to the size and orientation of the paleochannel.

In summary, inlet-driven processes that affect adjacent coastlines, such as shoal attachment, channel migrations and beach width variations, are capable of inducing changes in local coastal dunes depending on the scales involved. Our data analysis results show that the rate of volume increase in dunes that occur within the ebb-tidal dominated zone are significantly higher than dunes outside the zone. This occurs mainly where azimuth variations induced by ebb-tidal delta processes increases aeolian sediment supply, and not necessarily by the ongoing shoal attachment process. Furthermore, modelling results show that significant changes at the dunes are related with the potential of inlet-induced shoreline change. Dunes were significantly larger in the shoal attachment zone only in modelling scenarios where changes in beach width were large and persistent. Those situations, when integrated over time, lead to a significant increase in supply to the dunes, resulting in a noticeable larger foredune.

\section{Conclusions}

A case study on the island of Terschelling was carried out to understand how shoal attachment processes influence dune growth. The case was approached through a combination of the analysis of pre-existing topographic and bathymetric data, combined with an idealised and exploratory numerical modelling exercise using a cellular automata model. The higher rates of dune volume increase found in the island could not be associated with the increase in beach width lead by shoal attachments. Instead, larger dunes were associated with a long-term tidal inlet-induced shaping of the shoreline. Such a long-term process oriented the beach towards a beneficial direction for wind-driven sediment supply. The lack of direct influence of the shoals could be explained by the scale of control of the shoal on beach width in both time and space. A statistically different dune volume emerged only when shoals were capable of increasing beach width and long-term supply considerably. Such a situation occurred with lower rates of alongshore spreading and large beach width increase, suggesting that only specific shoal size and spreading characteristics can define a volume footprint at the dunes. Therefore, in the studied time-scale, subsequent shoal attachments are only capable of inducing a local increase in dune growth if their size and volume are large enough to create a wider beach for a long time interval, producing a high and persistent increase in supply.

Author Contributions: Conceptualisation, investigation, methodology, validation and writing-review and editing were performed by all authors. Data curation, formal analysis, software and writing-original draft was performed by F.G.-S. Funding acquisition, project administration, resources were performed by K.M.W. Supervision was performed by K.M.W. and S.J.M.H.H. All authors have read and agreed to the published version of the manuscript.

Funding: This research forms a component of the CoCoChannel project (Co-designing Coasts using natural Channel-shoal dynamics), which is funded by the Netherlands Organization for Scientific Research, Earth Sciences division (NWO-ALW), and co-funded by Hoogheemraadschap Hollands Noorderkwartier.

Acknowledgments: We further wish to acknowledge Rijkswaterstaat and KNMI for making their valuable bathymetric and topographic data sets freely available, as well as the water level, wave and wind data. Furthermore, we would like to thank Alma V. de Groot for making the model available and her comments in the initial stages of the research, and Angels Fernandez-Mora for the discussions regarding the shoreline model.

Conflicts of Interest: The authors declare no conflict of interest. The funders had no role in the design of the study; in the collection, analyses, or interpretation of data; in the writing of the manuscript, or in the decision to publish the results.

\section{References}

1. Hesp, P. Morphodynamics of incipient foredunes in new south wales, australia. Dev. Sedimentol. 1983, 38, 325-342. [CrossRef] 
2. Bauer, B.O.; Davidson-Arnott, R.G.D.; Hesp, P.a.; Namikas, S.L.; Ollerhead, J.; Walker, I.J. Aeolian sediment transport on a beach: Surface moisture, wind fetch, and mean transport. Geomorphology 2009, 105, 106-116. [CrossRef]

3. Bochev-van der Burgh, L.M.; Wijnberg, K.M.; Hulscher, S.J.M.H. Dune Morphology along a Nourished Coastline. J. Coast. Res. 2009, 2009, 292-296. [CrossRef]

4. Bochev-van der Burgh, L.M.; Wijnberg, K.; Hulscher, S.J.M.H. Decadal-scale morphologic variability of managed coastal dunes. Coast. Eng. 2011, 58, 927-936. [CrossRef]

5. Keijsers, J.G.; De Groot, A.V.; Riksen, M.J. Vegetation and sedimentation on coastal foredunes. Geomorphology 2015, 228, 723-734. [CrossRef]

6. van Puijenbroek, M.E.; Limpens, J.; de Groot, A.V.; Riksen, M.J.; Gleichman, M.; Slim, P.A.; van Dobben, H.F.; Berendse, F. Embryo dune development drivers: Beach morphology, growing season precipitation, and storms. Earth Surf. Process. Landf. 2017, 4144. [CrossRef]

7. Galiforni-Silva, F.; Wijnberg, K.M.; de Groot, A.V.; Hulscher, S.J.M.H. The effects of beach width variability on coastal dune development at decadal scales. Geomorphology 2019, 329, 58-69. [CrossRef]

8. Ruessink, B.G.; Jeuken, M.C.J.L. Dunefoot dynamics along the Dutch coast. Earth Surf. Process. Landf. 2002, 27, 1043-1056. [CrossRef]

9. Hesp, P. Foredunes and blowouts: Initiation, geomorphology and dynamics. Geomorphology 2002, 48, $245-268$. [CrossRef]

10. Houser, C.; Ellis, J. Beach and Dune interaction. In Treatise on Geomorphology; Elsevier: Amsterdam, The Netherlands, 2013; Volume 10, pp. 267-288. [CrossRef]

11. Galiforni-Silva, F.; Wijnberg, K.M.; de Groot, A.V.; Hulscher, S.J.M.H. The influence of groundwater depth on coastal dune development at sand flats close to inlets. Ocean Dyn. 2018. [CrossRef]

12. Davidson-Arnott, R.G.D.; Law, M.N. Measurement and Prediction of Long-Term Sediment Supply to Coastal Foredunes. J. Coast. Res. 1996, 12, 654-663.

13. Bauer, B.O.; Davidson-Arnott, R.G.D. A general framework for modeling sediment supply to coastal dunes including wind angle, beach geometry, and fetch effects. Geomorphology 2002, 49, 89-108. [CrossRef]

14. Hesp, P.A.; Smyth, T.A. Surfzone-Beach-Dune interactions: Flow and Sediment Transport across the Intertidal Beach and Backshore. J. Coast. Res. 2016, 8-12. [CrossRef]

15. Aagaard, T.; Davidson-Arnott, R.; Greenwood, B.; Nielsen, J. Sediment supply from shoreface to dunes: Linking sediment transport measurements and long-term morphological evolution. Geomorphology 2004, 60, 205-224. [CrossRef]

16. Stewart, C.J.; Davidson-Arnott, R.G. Morphology, formation and migration of longshore sandwaves; Long Point, Lake Erie, Canada. Mar. Geol. 1988, 81, 63-77. [CrossRef]

17. Davidson-Arnott, R.G.D.; Heyningen, A.G.V. Migration and sedimentology of longshore sandwaves, Long Point, Lake Erie, Canada. Sedimentology 2003, 50, 1123-1137. [CrossRef]

18. FitzGerald, D.M.; Buynevich, I.V.; Fenster, M.S.; McKinlay, P.A. Sand dynamics at the mouth of a rock-bound, tide-dominated estuary. Sediment. Geol. 2000, 131, 25-49. [CrossRef]

19. FitzGerald, D.M. Shoreline Erosional-Depositional Processes Associated with Tidal Inlets. In Hydrodynamics and Sediment Dynamics of Tidal Inlets; Springer: New York, NY, USA, 1988; pp. 186-225. [CrossRef]

20. Fenster, M.; Dolan, R. Assessing the impact of tidal inlets on adjacent barrier island shorelines. J. Coast. Res. 1996, 12, 294-310.

21. Siegle, E.; Asp, N.E. Wave refraction and longshore transport patterns along the southern Santa Catarina coast. Braz. J. Oceanogr. 2007, 55, 109-120. [CrossRef]

22. Galiforni-Silva, F.; de Oliveira Sousa, P.H.G.; Siegle, E. Longshore transport gradients and erosion processes along the Ilha Comprida (Brazil) beach system. Ocean Dyn. 2016, 1-13. [CrossRef]

23. Robin, N.; Levoy, F.; Monfort, O.; Anthony, E. Short-term to decadal-scale onshore bar migration and shoreline changes in the vicinity of a megatidal ebb delta. J. Geophys. Res. 2009, 114. [CrossRef]

24. Elias, E.P.L.L.; Van Der Spek, A.J.F.F. Long-term morphodynamic evolution of Texel Inlet and its ebb-tidal delta (The Netherlands). Mar. Geol. 2006, 225, 5-21. [CrossRef]

25. Do, A.T.; de Vries, S.; Stive, M.J. Beach Evolution Adjacent to a Seasonally Varying Tidal Inlet in Central Vietnam. J. Coast. Res. 2018, 341, 6-25. [CrossRef]

26. Isla, F.I. Seasonal behaviour of Mas Chiquita Tidal Inlet in relation to adjacent beaches, Argentina. J. Coast. Res. 1997, 13, 1221-1232. 
27. Fitzgerald, D.M.; Penland, S.; Nummedal, D. Control of Barrier Island Shape By Inlet Sediment Bypassing: East Frisian Islands, West Germany. Mar. Geol. 1984, 60, 355-376. [CrossRef]

28. Hayes, M.O. Development of Kiawah Island; Coastal Sediments 1977; ASCE: Reston, VA, USA, 1977; pp. 828-847.

29. O'Connor, M.C.; Cooper, J.A.G.; Jackson, D.W.T. Decadal Behavior of Tidal Inlet-Associated Beach Systems, Northwest Ireland, in Relation to Climate Forcing. J. Sediment. Res. 2011, 81, 38. [CrossRef]

30. Galiforni-Silva, F.; Wijnberg, K.M.; Hulscher, S.J.H.M. The role of water level in Aeolian dune development near inlets. In Proceedings of the 18th Physics of Estuaries and Coastal Seas Conference (PECS 2016), The Haque, The Netherlands, 9-14 October 2016.

31. Wijnberg, K.M.; van der Spek, A.J.; Silva, F.G.; Elias, E.; van der Wegen, M.; Slinger, J.H. Connecting subtidal and subaerial sand transport pathways in the Texel inlet system. Coast. Dyn. Proc. 2017, 235, 323-332.

32. Galiforni-Silva, F.; Wijnberg, K.M.; Hulscher, S.J.M.H. Storm-induced sediment supply to coastal dunes on sand flats. Earth Surf. Dyn. 2020, 8, 335-350. [CrossRef]

33. Grunnet, N.M.; Ruessink, B.G. Morphodynamic response of nearshore bars to a shoreface nourishment. Coast. Eng. 2005, 52, 119-137. [CrossRef]

34. Ruessink, B.; Kroon, A. The behaviour of a multiple bar system in the nearshore zone of Terschelling, the Netherlands: 1965-1993. Mar. Geol. 1994, 121, 187-197. [CrossRef]

35. Ridderinkhof, W.; Hoekstra, P.; van der Vegt, M.; de Swart, H. Cyclic behavior of sandy shoals on the ebb-tidal deltas of the Wadden Sea. Cont. Shelf Res. 2016, 115, 14-26. [CrossRef]

36. Ruessink, B.; Houwman, K.; Hoekstra, P. The systematic contribution of transporting mechanisms to the cross-shore sediment transport in water depths of 3 to $9 \mathrm{~m}$. Mar. Geol. 1998, 152, 295-324. [CrossRef]

37. Ketner-Oostra, H. Lichen-Rich Coastal and Inland Sand Dunes (Corynephorion) in the Netherlands: Vegetation Dynamics and Nature Management. Ph.D. Thesis, Wageningen University, Wageningen, The Netherlands, 2006.

38. Wiegmann, E.; Perluka, R.; Oude Elberink, S.; Vogelzang, J. Vaklodingen: De Inwintechnieken en hun Combinaties; Technical Report; Report AGI-2005-GSMH-012; Ministry of Transport and Public Works, Rijkswaterstaat, Adviesdienst GeoInformatie: Delft, The Netherlands, 2005.

39. Perluka, R.; Wiegmann, E.; Jordans, R.; Swart, L. Opnametechnieken Waddenzee; Report AGI-2006-GPMP-004, Technical Report; Rijkswaterstaat, Adviesdienst Geo Informatie en ICT: Delft, The Netherlands, 2006.

40. Alkemade, I.S.W. Kwaliteitsdocument Laseraltimetrie Deel 2: Resultaten Controles Kust 2007. Adviesdienst Geo-Informatie en ICT; Technical Report; Rijkswaterstaat: Delft, The Netherlands, 2007.

41. de Winter, R.; Gongriep, F.; Ruessink, B. Observations and modeling of alongshore variability in dune erosion at Egmond aan Zee, the Netherlands. Coast. Eng. 2015, 99, 167-175. [CrossRef]

42. Quartel, S.; Kroon, A.; Ruessink, B. Seasonal accretion and erosion patterns of a microtidal sandy beach. Mar. Geol. 2008, 250, 19-33. [CrossRef]

43. Keijsers, J.G.S.; Poortinga, A.; Riksen, M.J.P.M.; Maroulis, J. Spatio-temporal variability in accretion and erosion of coastal foredunes in the Netherlands: Regional climate and local topography. PLoS ONE 2014, 9, e91115. [CrossRef] [PubMed]

44. de Vries, S.; Southgate, H.N.; Kanning, W.; Ranasinghe, R. Dune behavior and aeolian transport on decadal timescales. Coast. Eng. 2012, 67, 41-53. [CrossRef]

45. Duarte-Campos, L.; Wijnberg, K.M.; Hulscher, S.J.M.H. Estimating Annual Onshore Aeolian Sand Supply from the Intertidal Beach Using an Aggregated-Scale Transport Formula. J. Mar. Sci. Eng. 2018, 6, 127. [CrossRef]

46. Donker, J.; van Maarseveen, M.; Ruessink, G. Spatio-Temporal Variations in Foredune Dynamics Determined with Mobile Laser Scanning. J. Mar. Sci. Eng. 2018, 6, 126. [CrossRef]

47. de Groot, A.; de Vries, S.; Keijsers, J.G.S.; Riksen, M.J.P.M.; van Ye, Q.; Poortinga, A.; Arens, S.M.; Bochev-Van der Burgh, L.M.; Wijnberg, K.M.; Schretlen, J.L.; et al. Measuring and modeling coastal dune development in the Netherlands. In Proceedings of the NCK-days 2012: Crossing Borders in Coastal Research, Enschede, The Netherlands, 13-16 March 2012; p. 6. [CrossRef]

48. Keijsers, J.G.S.; Groot, A.V.D.; Riksen, M.J.P.M. Modeling the biogeomorphic evolution of coastal dunes in response to climate change. J. Geophys. Res. Earth Surf. 2016, 121, 1161-1181. [CrossRef]

49. Baas, A.C. Chaos, fractals and self-organization in coastal geomorphology: simulating dune landscapes in vegetated environments. Geomorphology 2002, 48, 309-328. [CrossRef] 
50. Baas, A.C.W.; Nield, J.M. Modelling vegetated dune landscapes. Geophys. Res. Lett. 2007, 34 , L06405. [CrossRef]

51. Nield, J.M.; Baas, A.C.W. Investigating parabolic and nebkha dune formatrion using a cellular automaton modelling approach. Earth Surf. Process. Landf. 2007, 33, 724-740. [CrossRef]

52. Zhang, W.; Schneider, R.; Kolb, J.; Teichmann, T.; Dudzinska-Nowak, J.; Harff, J.; Hanebuth, T.J. Land-sea interaction and morphogenesis of coastal foredunes-A modeling case study from the southern Baltic Sea coast. Coast. Eng. 2015, 99, 148-166. [CrossRef]

53. Nield, J.M.; Baas, A.C. The influence of different environmental and climatic conditions on vegetated aeolian dune landscape development and response. Glob. Planet. Chang. 2008, 64, 76-92. [CrossRef]

54. Baas, A.C.W.; Nield, J.M. Ecogeomorphic state variables and phase-space construction for quantifying the evolution of vegetated aeolian landscapes. Earth Surf. Process. Landf. 2010, 731. [CrossRef]

55. Baas, A.C. Complex systems in aeolian geomorphology. Geomorphology 2007, 91, 311-331. [CrossRef]

56. Fonstad, M.a. Cellular automata as analysis and synthesis engines at the geomorphology-ecology interface. Geomorphology 2006, 77, 217-234. [CrossRef]

57. Stockdon, H.F.; Holman, R.A.; Howd, P.A.; Sallenger, A.H. Empirical parameterization of setup, swash, and runup. Coast. Eng. 2006, 53, 573-588. [CrossRef]

58. Thevenot, M.M.; Kraus, N.C. Longshore sand waves at Southampton Beach, New York: Observation and numerical simulation of their movement. Mar. Geol. 1995, 126, 249-269. [CrossRef]

59. Dean, R.G. Equilibrium Beach Profiles: Characteristics and Applications. J. Coast. Res. 1991, 7, 53-84. [CrossRef]

60. Hoad, K.; Robinson, S.; Davies, R. AutoSimOA: A framework for automated analysis of simulation output. J. Simul. 2011, 5, 9-24. [CrossRef]

61. Law, A.M. Simulation Modeling and Analysis; McGraw-Hill Education-Europe: Boston, MA, USA, 2014.

62. Davidson-Arnott, R.G.; MacQuarrie, K.; Aagaard, T. The effect of wind gusts, moisture content and fetch length on sand transport on a beach. Geomorphology 2005, 68, 115-129. [CrossRef]

63. Delgado-Fernandez, I. A review of the application of the fetch effect to modelling sand supply to coastal foredunes. Aeolian Res. 2010, 2, 61-70. [CrossRef]

64. Houser, C. Synchronization of transport and supply in beach-dune interaction. Prog. Phys. Geogr. 2009, 33, 733-746. [CrossRef]

65. Phillips, M.S.; Harley, M.D.; Turner, I.L.; Splinter, K.D.; Cox, R.J. Shoreline recovery on wave-dominated sandy coastlines: The role of sandbar morphodynamics and nearshore wave parameters. Mar. Geol. 2017, 385, 146-159. [CrossRef]

66. Bullard, J.E.; Ackerley, D.; Millett, J.; Chandler, J.H.; Montreuil, A.L. Post-storm geomorphic recovery and resilience of a prograding coastal dune system. Environ. Res. Commun. 2019, 1, 011004. [CrossRef]

67. Masselink, G.; Hughes, M.; Knight, J. Introduction to Coastal Processes and Geomorphology; Taylor \& Francis Ltd.: Abingdon, UK, 2014.

68. Jungerius, P.D.; Witter, J.V.; van Boxel, J.H. The effects of changing wind regimes on the development of blowouts in the coastal dunes of The Netherlands. Landsc. Ecol. 1991, 6, 41-48. [CrossRef]

69. Aagaard, T.; Nielsen, J.; Jensen, S.G.; Friderichsen, J. Longshore sediment transport and coastal erosion at Skallingen, Denmark. Geogr. Tidsskr. Dan. J. Geogr. 2004, 104, 5-14. [CrossRef]

70. Cohn, N.; Ruggiero, P.; de Vries, S.; García-Medina, G. Beach Growth driven by intertidal sandbar welding. In Proceedings of the Coastal Dynamics, At Helsingor, Denmark, 12-16 June 2017.

71. de Vries, S.; Verheijen, A.; Hoonhout, B.; Vos, S.; Cohn, N.; Ruggiero, P. Measured spatial variability of beach erosion due to aeolian processes. In Proceedings of the Coastal Dynamics, At Helsingor, Denmark, 12-16 June 2017.

72. Houser, C.; Hapke, C.; Hamilton, S. Controls on coastal dune morphology, shoreline erosion and barrier island response to extreme storms. Geomorphology 2008, 100, 223-240. [CrossRef]

73. Zarnetske, P.L.; Ruggiero, P.; Seabloom, E.W.; Hacker, S.D. Coastal foredune evolution: The relative influence of vegetation and sand supply in the US Pacific Northwest. J. R. Soc. Interface 2015, 12. [CrossRef] 
74. Goldstein, E.B.; Moore, L.J.; Vinent, O.D. Lateral vegetation growth rates exert control on coastal foredune hummockiness and coalescing time. Earth Surf. Dyn. 2017, 5, 417-427. [CrossRef]

75. Wernette, P.A.; Houser, C.; Weymer, B.A.; Everett, M.E.; Bishop, M.P.; Reece, B. Directional dependency and coastal framework geology: Implications for barrier island resilience. Earth Surf. Dyn. 2018, 6, 1139-1153. [CrossRef]

(C) 2020 by the authors. Licensee MDPI, Basel, Switzerland. This article is an open access article distributed under the terms and conditions of the Creative Commons Attribution (CC BY) license (http://creativecommons.org/licenses/by/4.0/). 